THURSDAY, NOVEMBER 18, I915.

\section{SCIENCE FOR ALL.}

$\mathrm{T}^{\mathrm{H}}$ HE little attention given to science in education and in the public mind has been the theme of many essays and addresses. In both cases science is usually regarded as suitable for study by a select few only, and not as an essential part of all modern life and thought. Latin and Greek, history, and the literature of other times receive almost as much consideration now as they did before scientific discovery changed the whole aspect and outlook of life; and the mass of the people, as well as most of their leaders, are in their training deprived of light which should illumine the minds of all.

We do not for a moment suggest that the end of all education should be preparation for scientific careers; neither do we ask that men of letters, statesmen, and administrative officers of departments of State should all be scientific experts. To make such claims would be unreasonable, though not more so than the accepted principle that familiarity with classical languages and literatures is a necessary qualification for such positions, and that the first place must be given to these subjects even if matters more closely related to modern conditions of existence in war or in peace have to be, neglected. Our claim is that everyone-from elementary-school pupil to college don-should be made acquainted with appropriate outlines of scientific work and thought. We want science to be a part of every general education, and we urge that the times demand this recognition of its influence and potentialities. When this modernisation has been accomplished, facilities for scientific work will be increased a hundredfold, and the public will not be deceived by sensational announcements in the daily Press, or tolerate official indifference to the growth of natural knowledge.

It may be doubted whether the methods now followed in the teaching of scientific subjects in schools are as effective in creating or fostering interest in science as those formerly adopted. Twenty years ago or so, much more attention was given to the attractive side of science than is now the case. Pupils were shown interesting experiments or were encouraged to read about remarkable facts and phenomena in Nature; and if they took a practical course they were able to cover a fairly wide field. In physics, for example, a student could learn something about the whole elementary range-mechanics, heat, sound, light, electricity, and magnetism; in chemistry NO. 2403 , VOL. 96] he would see many striking changes and effects, such as impress themselves upon the youthful mind; in natural science he would be told many wonderful facts about birds and beasts and other objects-animate and inanimate--in the world of Nature.

No comprehensive survey of this kind is possible under existing conditions of science teaching in schools. In physics few students get beyond a course of work in mechanics and heat, and they leave school without receiving any instruction in other branches of the subject; their practical chemistry is frequently limited to manipulations and a study of air and water; and work in Nature-study means mainly the observation of a few facts of plant physiology or of animal development and habits.

Personal observation, intelligent inquiry, quantitative test, are, of course, essential factors of scientific method, but we believe that to insist upon all school science being controlled by them is a mistake. The limited amount of time that is given to science in schools renders true research methods impracticable; and pupils in general can scarcely be expected themselves to possess the motive and the purpose that lead to scientific investigation. Every teacher knows that only rarely is a pupil capable of initiating an experiment or of arriving at a statement of law or principle from results obtained by practical work. Little justification can be found, therefore, for the concentrated attention given to a few subjects, with the view of imparting knowledge of experimental methods, when such a course means that the wonders of the fields beyond are kept outside the range of vision.

School science as at present taught, and as defined by examination syllabuses, seems to proceed on the assumption that every pupil is to become a skilful experimenter, or an original investigator, in the realms of Nature. Courses of laboratory work designed with this intention may not unfairly be compared with the test-tubing of former times, which aimed at making every boy an analytical chemist. The practical work now done is certainly more valuable as a means of scientific training than it used to be, but it may be doubted whether by such exercises science can claim a prominent place in the curriculum. Modern life requires that the elements of scientific method and knowledge should form part of every educational course. School work should not be concerned in training experts in science, any more than specialists in classics, but with imparting the rudiments of a liberal education to all pupils, so as to awaken 
interest which will continue when schooldays are over.

That is the standard-abiding interest-by which successful teaching may be judged; and we are disposed to think that the descriptive and qualitative school science of a generation or two ago was better adapted to promote such continued attention than is the quantitative work in the narrow fields mapped out for instruction to-day. In their anxiety to impress pupils with a sense of scientific accuracy and cautious conclusion, advocates of the methods now in vogue have forgotten that it is even more important to present a view of science which shall be human as well as precise. To the general neglect of this aspect of scientific study, which appeals to all, must be ascribed the fact that science has lost much of its former popularity, and has become a task in which only a favoured few can hope to excel.

It is a thousand pities that science should be considered to be merely a burden of material fact and precise principle which needs a special type of mind to bear it. We want much more of the spirit, and less of the valley of dry bones, if science is to be made of living interest, either during school life or afterwards. We want everyone to know something of the lives and work of such men as Galileo and Newton, Pasteur and Lister, Darwin and Mendel, and many other pioneers of science. The way to inspire wide interest in the achievements of men like these is not by the laboratory teaching of a few, but by suitable descriptive literature for all. In books intended for general reading, information should be made subordinate to inspiration, and broad outlines of great discoveries or fruitful ideas should be presented instead of tedious detail. It should be shown that self-sacrifice, persistence, courage, duty, accuracy, love of truth, and like attributes of greatness, may all be abundantly exemplified from the careers of men of science.

The achievements of science represent increase of knowledge, not alone for the man who makes it, not alone also for the nation or country to which he belongs, but for the whole human race. The conquests of science do not mean the aggrandisement of one country or people at the expense of another, but gifts to all who will receive them. The only domain which it is desired to penetrate is that of ignorance; and the fight is against the physical and mental death which is its heritage. Ignorance made plague the terror of Europe in the Middle Ages; science has proved that the disease is due to a bacillus which is conveyed by fleas from rat to rat, and from rats suffering from the disease to mankind. Ignorance ascribed malaria to a miasma or bad air arising from marshy places; science has shown it to be carried from one human being to another by a certain species of mosquito. Ignorance of the cause of yellow fever made the regions around the Caribbean Sea the White Man's Grave, where the risk of death for the visitor was greater than in a battle; knowledge that the disease is communicated from an infected to a healthy person by the bite of a particular mosquito has been the means of converting the same places into tropical health resorts. One practical result of the discovery of the cause of yellow fever was that it made possible the construction of the Panama Canal. It was not a hostile army or political difficulties that obstructed the work commenced by de Lesseps, not mountain chain or desert waste, but an insect which raised a barrier of disease and death between endeavour and accomplishment.

We have in uplifting stories of this kind-and there are many others-plenty of themes for epics which, rightly used, will stimulate interest in science, in both old and young. When a place for such literature is found in every educational course, the number of people who will follow scientific work with sympathetic minds will be greatly increased. At present school science means mostly determinations of specific heats or chemical equivalents, and similar exercises, while the deeds and thoughts which give living interest to material studies are neglected altogether. We do not ask that science students only should be given much broader views of natural knowledge than can be acquired through laboratory manuals and class text-books, but that the historical and literary studies in all schools and colleges should include works in which great scientific achievements and generalisations are expounded. We are confident that such subjects can be made attractive to almost every mind, and that the want of general and intelligent interest in them is due largely to the neglect of descriptive scientific literature in all stages of instruction.

It is unfortunately true that men of science themselves are often interested only in their own special field of work, and pay little attention to what is being done in other directions. These are the days of specialised study, and though the high powers used for the eyepieces enable new details to be discerned, the field of view is greatly restricted in extent, and the sense of true proportion is lost. Specialisation is essential for advance, but when it also means indifference to external movements and influences, it does not repre- 
sent the highest type of intellectual activity. We cannot urge with any force the desirability of bringing the laity to appreciate the outstanding points of scientific work if specialists in particular sections of such work manifest no interest in the results of investigations by their colleagues in other departments, or will not trouble to make themselves understood outside their own esoteric circle. Papers read before scientific societies are now so highly specialised that only occasionally can they be followed with intelligent interest by the whole of the fellows present at a meeting, and usually not more than two or three people are capable of criticising them. As this is the case in circles where at any rate the general language of science is understood, it is not strange that people who have not had a scientific education should believe that scientific description must be beyond their comprehension.

This belief is probably responsible for the fact that there is little demand for popular works on science and few large audiences for scientific lecturers. We can say without fear of substantial contradiction that in such an inspiring subject, for example, as astronomy, attempts at popularisation by books or lectures have less chance of success than they had fifty or a hundred years ago. We are well aware that there are a few individual exceptions to this generalisation, but the statement can be fully justified as a whole, not only as regards astronomy, but also by the experiences of most authors and lecturers in other branches of science. There has been a vast increase in periodical publications and general literature, but the increase in scientific literature has been in the direction of text-books and treatises rather than in popular works, to which little encouragement is given, either by men of science or the public.

We should be sorry to suggest that scientific work is necessarily associated with poor literary style; indeed, we are sure that the literary compositions of men of science compare very favourably with those of other workers who are not purely men of letters. It may be doubted, however, whether sufficient encouragement is given to young scientific men to cultivate the power of clear expression, or whether sufficient appreciation is shown of efforts at making science intelligible to the people. An author like Mr. H. G. Wells, who creates wide interest in scientific work, is doing far better service to science than he would if he had concentrated his attention upon the minute biological structures of his early days as student and teacher. It would be greatly to the advantage of science if there were many more writers possessing like scientific knowledge with brilliant imagination and convincing pen.

Science can only secure its rightful position in a democratic State when its work and worth are widely known and understood. The makers of new knowledge can be trusted to continue to add to the stores already accumulated, but they should remember also that popular interest means increased support for their work and greater use of the results. It is rarely that great capacity for original investigation is combined with the gift of attractive exposition, and more rare to find both qualities being used for the popularisation of science, as, for example, in Sir Ray Lankester's series of masterly notes and essays, three volumes of which have now been published. We believe the influence of such literary work upon the public mind is much greater than is generally understood, and we should like to see many equally attractive efforts of a similar kind in other scientific fields than those with which Sir Ray Lankester is most intimately acquainted.

The war has made people think of more serious things than those which had their attention a year or two ago, and there are signs that a more satisfying literature will be required than the light pabulum which has hitherto served. What could be better adapted to provide for the coming need than the rich materials of science when attractively displayed? It is the privilege of scientific workers to have garnered these stores; and it is equally their duty to see that the nation does not perish for want of the stimulating food which they can furnish. If science does not come into its kingdom in the immediate future, it should not be for want of endeavour to enlighten the mind of the public and create intellectual interest in its aims, but because the people are content to be ignorant of the truths learned in the innermost courts of the temple of Nature, and to be without the power which such knowledge can give them.

ORIGIN OF THE INDIAN CASTE SYSTEM.

The People of India. By Sir H. Risley. Second edition, edited by W. Crooke. Pp. xxxii $+472+$ xxxv plates. (Calcutta and Simla: Thacker, Spink and Co. ; London: W. Thacker and Co., I9I5.) Price $2 x s$. net.

THIS memorial edition of the late Sir $H$. Risley's standard work on Indian anthropology has fortunately been entrusted to the competent hands of Mr. W. Crooke. As no notes were left by the author for a new edition, the editor has reproduced the text generally as it stood in the first, which had quickly run out of 